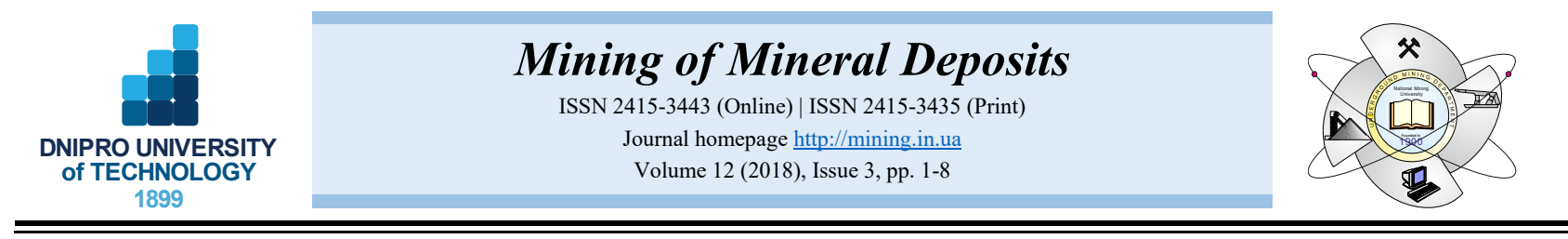

UDC 622.24 .08

https://doi.org/10.15407/mining12.03.001

\title{
DETERMINATION OF THE SUITABLE DRILLING OPERATING PARAMETERS IN DIFFERENT GEOLOGICAL FORMATIONS EL-SHARARA OIL FIELD (SOUTH-WESTERN LIBYA)
}

\author{
M.A. Sayed ${ }^{1}$, G.Y. Boghdady ${ }^{1}$, W.R. Abdellah ${ }^{1 *}$ \\ ${ }^{1}$ University of Assiut, Assiut, Egypt \\ *Corresponding author: e-mail wre544@gmail.com, tel.+20882336672
}

\begin{abstract}
Purpose. The objective of this study is to determine the best operating conditions for the most notable drilling parameters (i.e. weight on bit (WOB), rotary drilling speed (RPM), and characteristics of drilling fluid) using field data obtained from El-Sharara Oil Field.

Methods. The used data has been extracted from daily drilling reports of well named (NC-186/K04h) field. Such data contains information about the geological formations, casing strings, drill-bits, fuel consumption, flow rate of drilling fluid and other drilling parameters.

Findings. The results reveal that, the lower geological formations of El-Sharara Oil Field, the harder are the upper formations. Therefore, it is recommended to apply heavy loads (i.e. WOB of $45000 \mathrm{lb}$ ) with low drilling speed (i.e. $100 \mathrm{rpm}$ ) in the lower formations; and to apply small loads (i.e. WOB of $19000 \mathrm{lb}$ ) with high drilling speed (i.e. $160 \mathrm{rpm}$ ) in the upper formations.

Originality. This study evaluates the performance of drilling operation based on the interaction between rock formations and machine drilling parameters.

Practical implications. Understanding such interaction between rock formations and machine drilling parameters will remarkably improve the rate of penetration (ROP) in the related geological formations. Consequently, the overall drilling costs will be reduced in terms of drilling time, life of drill-bit and fuel consumption.
\end{abstract}

Keywords: improvement of drilling operation, operating parameters, rock properties, oil well drilling, El-Sharara Oil Field

\section{INTRODUCTION}

Drilling operation is frequently practised in geotechnical engineering, e.g. civil, petroleum and mining. The performance efficiency of drilling process mainly depends on rock properties, machine and operating parameters, particularly rate of penetration. The latter, e.g. ROP, can be used as a tool to estimate the strength properties of rock (Ali, Abdellah, \& Abd El-Aal, 2016).

Rock drillability could be predicted using different methods of analysis such as computer programming/simulator, regression analysis, specific energy (SE) index, dimensionless index of uniaxial compressive strength of rock/specific energy (UCS/SE), and information obtained from cores and/or cuttings. Simulator facilitates rapid deriving prediction equations which assist estimating the drilling costs and help selecting the type of drilling rig according to ground conditions. The starting point for numerical analysis is to obtain field data to be used as input parameters for the simulator in order to have predic- tions of the ROP as an output para-meter (Wijk, 1991; Abouzeid \& Cooper, 2003; Dahl, Grøv, \& Breivik, 2007).

Regression analysis can be conducted using a computing package called "Statgraphics-Statistical Graphic System" to develop a penetration rate models and to decide which variables should be included in the model (i.e. drill power and/or properties of the rock penetrated). Consequently, hundreds of models are resulted and then statistically are tested to select the best-fit model (Selim \& Bruce, 1970; Kahraman, 1999). The concept of SE is firstly suggested by Teale (Teale, 1965), Mellor (Mellor, 1972), Pathinkar and Misra (Pathinkar \& Misra, 1980), and Bilgin and Kahraman (Bilgin \& Kahraman, 2003) as a tool to evaluate rock drillability. SE is a function of ROP, torque (T), RPM and cross-sectional area of drill-bit (A) (Abdellah, 2007). The dimensionless index (UCS/SE) can also be employed to distinctly classify rock types by plotting that index against the obtained ROP (EL-Biblawi, Sayed, Mohamed, \& EL-Rawy, 2007a). 


\subsection{Major factors influencing ROP}

Resistance to penetration, shearing action of drill-bit during its rotation and the degree of abrasiveness are the major phenomena that would have an influence on the drilling efficiency. Estimating the drilling costs and identifying rock type and its properties based on prediction of ROP have become a big challenge issues in petroleum engineering. Such prediction might help drilling engineers to improve the capability of drilling operation. Well logging or wireline logging is used to measure some characteristics of geological formations such as electrical conductivity, radioactivity and porosity. Bit condition (i.e. wear degree, new and/or dull) has a great influence on the rate of drilling. Consequently, it affects the overall drilling costs. The bit wear is defined as removal of material from solid surfaces as a result of relative sliding motion at the contact surface. The life of drill-bit, replacement and/or maintenance costs are usually hard to be accurately predicted, because many factors influencing them are hard to be obtained (Sayed, 1992; Sayed, 1994; Sayed, 2009; Sayed, 2014).

In order to drill a well, three parameters have to be simultaneously combined. These are:

- certain load has to be applied on the drill-bit (i.e. thrust, WOB);

- the drill-bit has to be rotated (i.e. RPM);

- the drilling fluid has to be circulated within the well bore (i.e. fluid/mud characteristics).

Man power and hardware systems are the two principal components required to drill borehole. The first component (i.e. man power) consists of group of drilling engineers and rig operators. Such group is involved in many drilling activities like mud design, drill-bit/rig selection, casing and well-cementation, and well control and monitoring. The second component (i.e. hardware systems) includes power generation, hoisting, mud/fluid circulation; blow out control and drilling data acquisition system (Sayed, 2001; El-Biblawi, Sayed, Mohamed, \& El-Rawy, 2007; Osgouei, 2007; Sayed \& Boghdady, 2010; El-Biblawi, Sayed, Boghdady, \& Hamdallah, 2012; Seifabad \& Ehteshami, 2013).

Therefore, it is necessary to combine these two components (i.e. man power and hardware systems) together to improve the drilling operating parameters for an efficient drilling process. Improvement of the significant drilling operating parameters are necessary to reach reasonable drilling rate related to different geological formations in oil well drilling. Such improvement is extensively influenced by several factors some of which are controllable by the operator (i.e. thrust or weight on bit, drilling speed, fluid/mud properties, and bit type/conditions) and some are beyond the control of the operator (i.e. characteristics of geological formations). Thereby, thorough understanding of the relationship between these two parameters (i.e. controllable and noncontrollable) at any given site is mandatory to achieve such improvement (Libya Oil \& Gas Exploration Lows and Regulation Handbook). Therefore, this paper will use the information from El-Sharara Oil Field to estimate the suitable drilling operating conditions related to geological formations. The next section briefly presents the information about the area under the study.

\section{STUDYING AREA EL-SHARARA OIL FIELD}

The giant El-Sharara Oil Field is located in Block NC115 of the Murzuq basin, about $730 \mathrm{~km}$ south of Tripoli (Biggest Producing Fields in Libya; History of the petroleum industry). The map that illustrates the location of the area under the study is shown in Figure 1. The field was discovered by Petroleum Romanian Oil and Gas Company in the 1980's and later began production in December 1996. By 2006, it was producing about 200000 barrels per day (bpd) of high quality crude oil. Since mid of 1998, the light and sweet crude which was produced at El-Sharara has been exported by pipeline through the Zawia terminal west of Tripoli (Biggest Producing Fields in Libya).

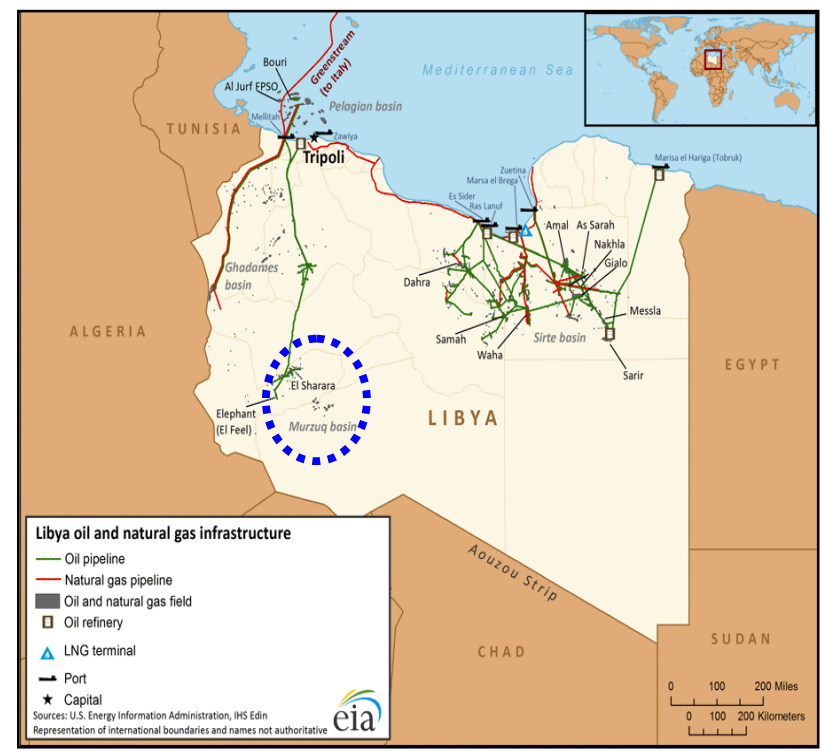

Figure 1. Location of El-Sharara Oil Field (Murzuq basin, Libya) (Biggest Producing Fields in Libya)

The field has a capacity of $400000 \mathrm{bpd}$ and before the outbreak of conflict in 2011 accounted for a quarter of Libyan production. Although, other sources site the maximum capacity lower at 340000 bpd. By February 2012, the National Organization Company announced that production at the site had again reached $300000 \mathrm{bpd}$, despite delays over security concerns (History of the petroleum industry).

Akakus Oil Operations Company is one of the largest oil companies operating in Libya and has pioneered, explored and eventually developed two major blocks in the Murzuq basin in the South-Western area of the Libyan Desert adjacent to the famous Akakus Mountain strip and the old city of Ubari. The company's field of activities is limited to the Exploration and Oil Production of the National Concessions (i.e. NC-115 and NC-186) including any other unforeseen new developments for the benefit of both parties.

\subsection{National Concession NC-115}

The primary Concession is initially developed by Akakus (i.e. formerly is known by Repsol Oil Operations) and is comprised of the Main Gas Oil Separation Plant (GOSP) " $A$ " and two other smaller GOSP's " $B$ " and " $\mathrm{H}$ ". This concession is the backbone of the field operations where all control and monitoring is done. The main Central Complex, Airport, warehouses, workshops and other supporting facilities are in this concession. 


\subsection{National Concession NC-186}

This is the recently developed Concession and is comprised of the main gas and oil separation plant (GOSP) " $\mathrm{A}$ " and the minor gathering satellite stations GS " $\mathrm{B}$ ", "D", "H", "J" and "K". All these facilities are interconnected by a network of trunk lines for facilitating oil movement and water injection mechanisms around the fields. The "I/R" development project, which is currently ongoing, is distributed among these two Concession due to the physical existence of the oil reservoir shared between the two concessions (Fello, 2001; Clark-Lowes, 2008). The drilling information that collected from a well named "NC-186/K04h" (i.e.) daily drilling reports and information about the drill-bits that are used in the drilling through a certain period is presented in the next section.

\section{DATA COLLECTION}

The daily drilling reports contain information about the geological formations, casing strings, drill-bits, fuel consumption, drilling fluid flow rate and drilling parameters. This research focuses on the operating parameter (i.e. WOB, RPM) and some related drilling parameters (i.e. ROP, fuel consumption and drilling fluid flow rate). Daily reports, from well named (NC-186/K04h), give the important drilling parameters as listed in Table 1. Similarly, other daily drilling reports for the same well (i.e. reports No. 57 to 91) are used to extract important drilling parameters and reports No. 13 to 33 are used from another well named "NC-115/M16i", as well as from well named "NC.115/WSW.37".

Table 1. Important drilling parameters extracted from daily reports (No. 11 to 55) during one month

\begin{tabular}{|c|c|c|c|c|c|c|c|}
\hline Depth, $\mathrm{ft}$ & $\begin{array}{l}\text { Drilling } \\
\text { time, } \mathrm{hr}\end{array}$ & $\mathrm{ROP}, \mathrm{ft} / \mathrm{hr}$ & RPM, rpm & $\begin{array}{l}\text { WOB, } \\
1000 \mathrm{lb}\end{array}$ & $\begin{array}{c}\text { Fuel consumption, } \\
\mathrm{gal} / \mathrm{hr}\end{array}$ & $\begin{array}{l}\text { Fluid flow } \\
\text { rate, gpm }\end{array}$ & Report No. \\
\hline 125 & 4.00 & 31.2 & 55 & 8 & 25 & 261 & 11 \\
\hline 587 & 17.50 & 335.0 & 120 & 18 & 30 & 800 & 12 \\
\hline 554 & 10.00 & 55.4 & 100 & 40 & 40 & 840 & 13 \\
\hline 267 & 11.70 & 22.8 & 120 & 40 & 50 & 861 & 14 \\
\hline 27 & 2.00 & 13.5 & 75 & 20 & 25 & 660 & 16 \\
\hline 781 & 14.80 & 52.8 & 115 & 30 & 45 & 740 & 17 \\
\hline 26 & 2.00 & 13.0 & 95 & 8 & 30 & 590 & 18 \\
\hline 276 & 20.00 & 13.8 & 157 & 12 & 45 & 700 & 19 \\
\hline 276 & 17.00 & 16.2 & 170 & 14 & 50 & 720 & 20 \\
\hline 437 & 16.00 & 27.3 & 183 & 18 & - & 805 & 21 \\
\hline 285 & 18.50 & 15.4 & 180 & 18 & 60 & 805 & 22 \\
\hline 285 & 6.30 & 21.4 & 80 & 18 & 60 & 805 & 23 \\
\hline 253 & 10.20 & 24.8 & 186 & 15 & - & 810 & 24 \\
\hline 385 & 16.20 & 26.4 & 181 & 14 & 60 & 810 & 25 \\
\hline 192 & 12.22 & 15.7 & 181 & 20 & 60 & 650 & 26 \\
\hline 38 & 8.50 & 3.3 & 150 & 38 & 45 & 650 & 28 \\
\hline 80 & 20.00 & 4.0 & 146 & 45 & 50 & 600 & 29 \\
\hline 54 & 22.60 & 2.4 & 160 & 50 & 50 & 680 & 30 \\
\hline 27 & 9.20 & 2.9 & 162 & 34 & 50 & 680 & 31 \\
\hline 46 & 12.75 & 3.6 & 108 & 40 & 35 & 680 & 32 \\
\hline 56 & 19.00 & 2.9 & 112 & 42 & 55 & 700 & 33 \\
\hline 35 & 12.10 & 2.9 & 162 & 42 & 55 & 700 & 34 \\
\hline 368 & 17.30 & 21.2 & 170 & 20 & 40 & 750 & 52 \\
\hline 310 & 16.58 & 18.7 & 170 & 24 & 45 & 750 & 53 \\
\hline 220 & 19.52 & 11.3 & 170 & 25 & 50 & 700 & 54 \\
\hline 111 & 13.60 & 8.2 & 170 & 25 & 55 & 740 & 55 \\
\hline
\end{tabular}

\section{RESULTS AND DISCUSSIONS}

The collected data indicate that the wells were drilled through different geological formations. The Murzuq basin, South-west Libya, is formed due to series of Palaeozoic intracratonic sag basins on the North African Saharan Platform. The structural fabric of the basin has been developed during the late Proterozoic Pan-African orogenic event. Thus, it is greatly influenced the depositional patterns and stratigraphy of the basin. According to the wireline log response, grain-size and the proportion of sandstone to shale, the Murzuq formations are divided into lower and upper.

The latter, upper formations, comprises mainly from sandstone with coarse to very coarse grained. Whereas, the lower formation is characterized by the presence of sandstone dominated coarsening-upward sequence accompanied by increased bioturbation towards the northeast (Fello, 2001). Therefore, in this paper the two formations are called upper and lower. The average values of drilling parameters for upper formations, in terms of ROP, flow rate of drilling fluid, fuel consumption at constant high speed and varied WOB, are given in Table 2 .

\subsection{Effect of WOB on ROP - upper formations}

The relationship between WOB and ROP, at high RPM and WOB, is depicted in Figure 2. It can be shown that, the ROP increases with the increase of WOB. The ROP gradually increases until it reaches the maximum value of $21.4 \mathrm{ft} / \mathrm{hr}$ at WOB of $19000 \mathrm{lb}$. Afterwards, the ROP becomes constant or gradually decreases (i.e. due to wear occurrence to drill-bit). 
Table 2. Average values of ROP, fluid flow rate and fuel consumption at high speed and low WOB in upper formations

\begin{tabular}{cccc}
\hline $\begin{array}{c}\text { WOB, } \\
1000 \mathrm{lb}\end{array}$ & $\begin{array}{c}\text { Average values } \\
\text { of ROP, ft/hr }\end{array}$ & $\begin{array}{c}\text { Average values } \\
\text { of fluid flow rate, gpm }\end{array}$ & $\begin{array}{c}\text { Average values } \\
\text { of fuel consumption, gal } / \mathrm{hr}\end{array}$ \\
\hline 12 & 13.80 & 700 & 45 \\
14 & 16.20 & 720 & 50 \\
15 & 18.05 & 750 & 53 \\
18 & 21.20 & 750 & 55 \\
19 & 21.40 & 805 & 55 \\
20 & 21.20 & 805 & 60 \\
24 & 18.70 & 810 & 40 \\
25 & 11.30 & 710 & 54 \\
12 & 13.80 & 700 & 45 \\
\hline
\end{tabular}

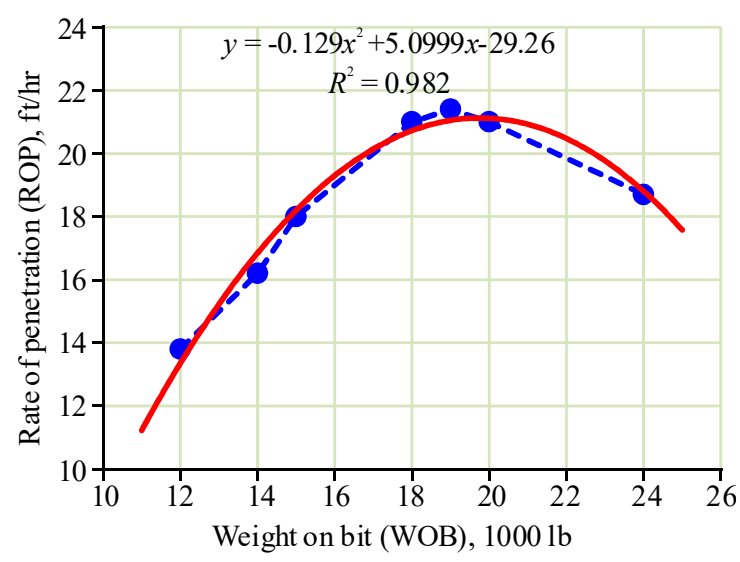

Figure 2. Variation of ROP at different $\mathrm{WOB}$ at low WOB and high RPM

\subsection{Effect of RPM on the fuel} consumption - upper formations

The fuel consumption exceeds as RPM increases as shown in Figure 3. It can be shown that, the suitable drilling speed which gives the lowest amount of fuel consumption is $55 \mathrm{rpm}$. The values of the ROP and fuel consumption at various RPMs and WOB, for the upper geological formations, is given in Table 3 .

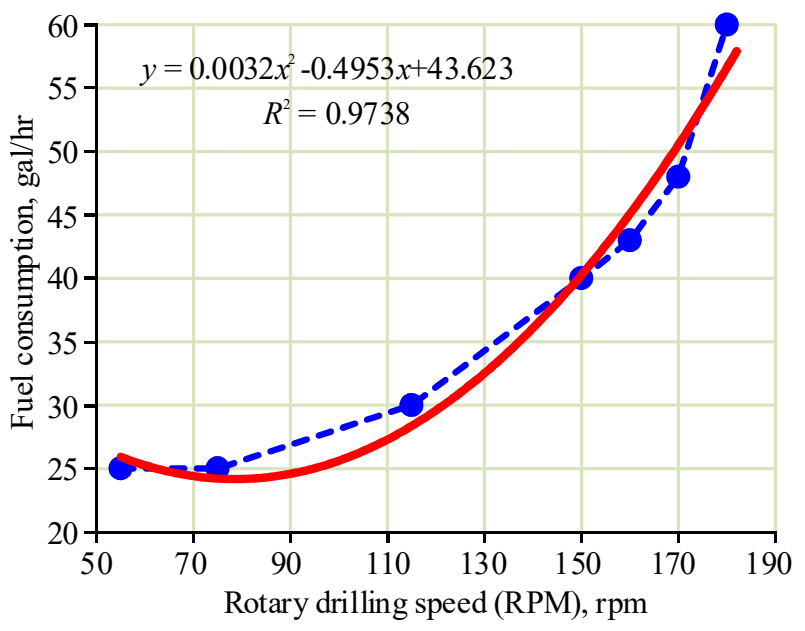

Figure 3. Fuel consumption against RPM at low WOB of $20000 \mathrm{lb}$

\subsection{Effect of RPM on ROP and fuel consumption - upper formations}

The relationship between ROP and RPM is displayed in Figure 4. It is shown that, the maximum value of ROP (i.e. $55.4 \mathrm{ft} / \mathrm{hr}$ ) is obtained at low RPM.
Table 3. The average values of ROP and fuel consumption

\begin{tabular}{ccc}
\hline RPM, rpm & ROP, ft/hr & $\begin{array}{c}\text { Fuel consumption, } \\
\text { gal/hr }\end{array}$ \\
\hline 100 & 55.4 & 40 \\
115 & 52.8 & 45 \\
120 & 22.8 & 50 \\
140 & 4.0 & 50 \\
150 & 3.3 & 55 \\
160 & 2.9 & 50 \\
\hline
\end{tabular}

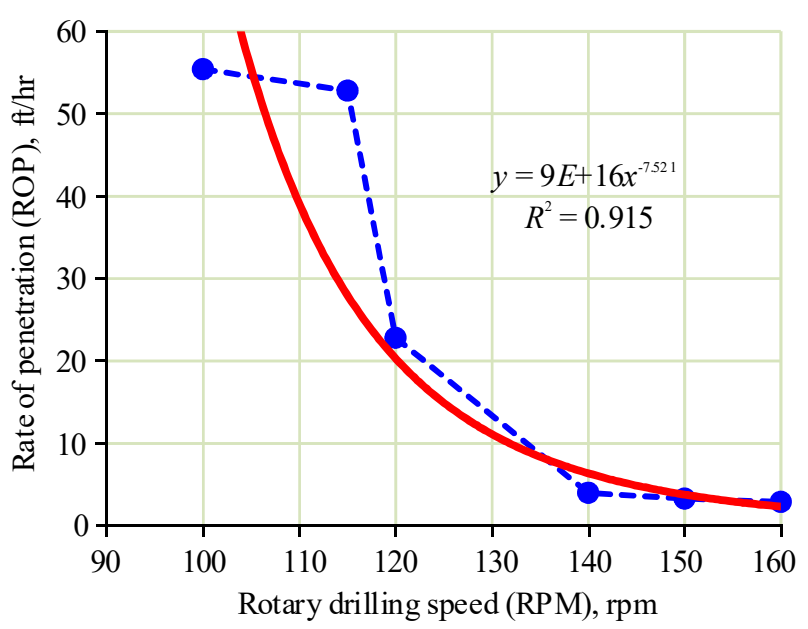

Figure 4. Relationship between ROP and RPM at high WOB $45000 \mathrm{lb}$

However, ROP decreases if the RPM and WOB increase. The reason for that is the soft formations are more sensitive to RPM variations than WOB. On contrary, the hardest formations are likely sensitive to WOB change than RPM. In addition, the wear of the drill-bit increases as WOB and RPM increase.

\subsection{Effect of WOB on ROP - lower group of formations}

The relationship between fuel consumption at various RPMs is shown in Figure 5. It is obvious that, the fuel consumption increases as rotary drilling speed increases. Also, the optimum RPM that gives the maximum value of ROP is $100 \mathrm{rpm}$, as shown in Figure 4 and 5.

The average values of ROP, fluid flow rate and fuel consumption at constant high speed and different weight on bit for the lower formations are listed in Table 4.

The relationship between WOB and ROP, at constant high speed, is depicted as shown in Figure 6. It can be shown that, the ROP increases as WOB increases. 


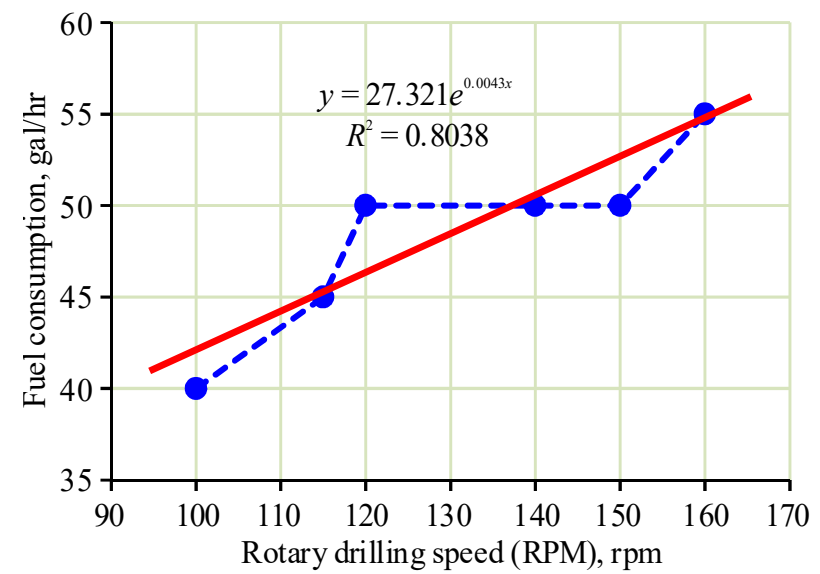

Figure 5. Relationship between fuel consumption and RPM at low WOB of $20000 \mathrm{lb}$

Table 4. The average values of ROP, fluid flow rate and fuel consumption at high RPM and low WOB for the lower formations

\begin{tabular}{cccc}
\hline $\begin{array}{c}\text { WOB, } \\
1000 \mathrm{lb}\end{array}$ & $\begin{array}{c}\text { ROP, } \\
\mathrm{ft} / \mathrm{hr}\end{array}$ & $\begin{array}{c}\text { Flow rate, } \\
\mathrm{gpm}\end{array}$ & $\begin{array}{c}\text { Fuel consumption, } \\
\mathrm{gal} / \mathrm{hr}\end{array}$ \\
\hline 13 & 6.6 & 430 & 40 \\
15 & 6.4 & 430 & 50 \\
18 & 8.5 & 700 & 30 \\
19 & 7.6 & 500 & 50 \\
20 & 8.8 & 400 & 50 \\
25 & 6.6 & 780 & 55 \\
30 & 6.8 & 675 & 30 \\
\hline
\end{tabular}

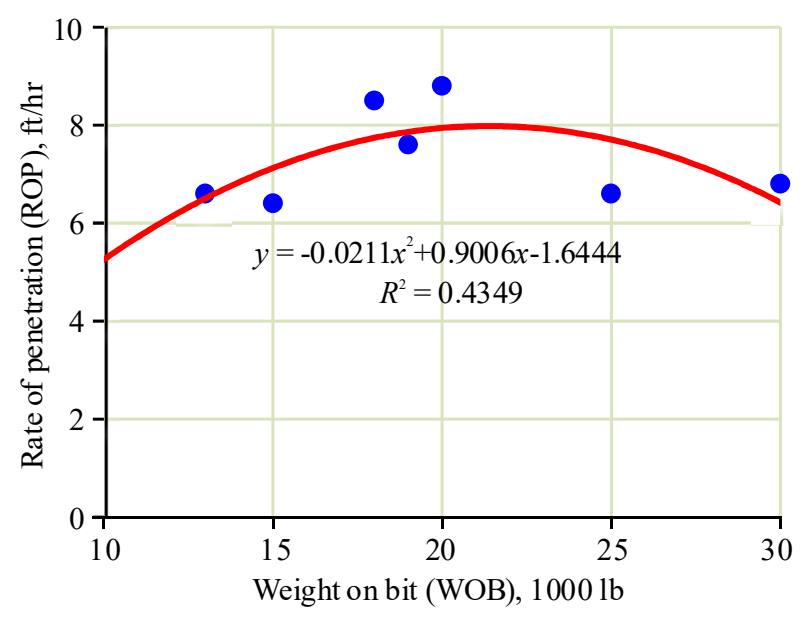

Figure 6. ROP versus WOB at constant RPM of $175 \mathrm{rpm}$

The values of penetration rate increases gradually until the maximum RPM reaches $8.8 \mathrm{ft} / \mathrm{hr}$ at WOB of $20000 \mathrm{lb}$.

\subsection{Effect of RPM on ROP and fuel consumption - lower formations}

The results show that the harder formations (i.e. lower formations) are more sensitive to the increase in the WOB rather than increase in RPM as shown in Figure 7. High RPM leads to decrease in the values of ROP and increase the bit wear (i.e. increase friction with formations). It is found that, the suitable RPM is $160 \mathrm{rpm}$ which gives the suitable ROP in hard formations.

The relationship between fuel consumption and RPM is displayed as shown in Figure 8.

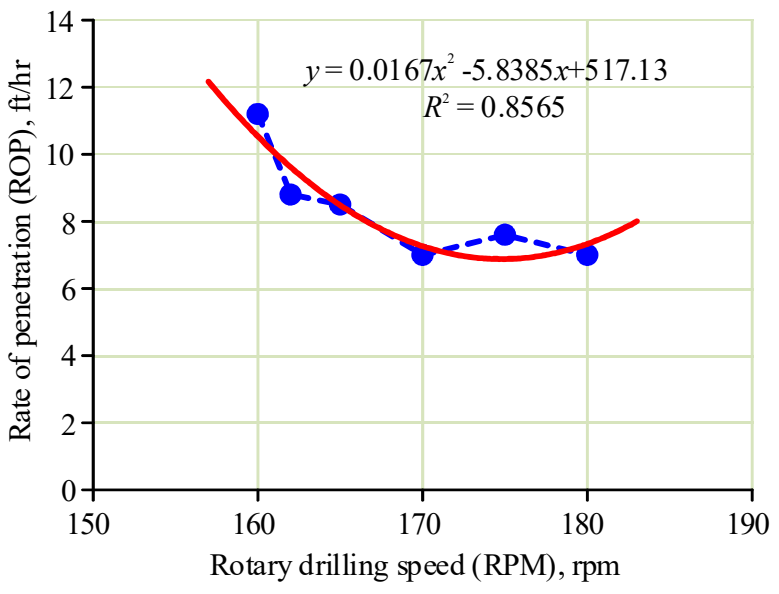

Figure 7. ROP against the RPM at constant WOB of $20000 \mathrm{lb}$ (lower formations)

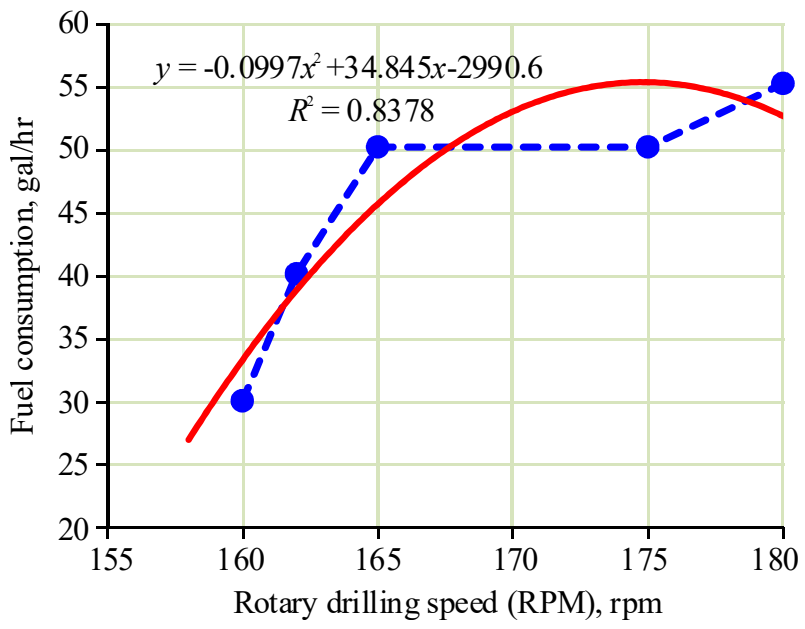

Figure 8. Fuel consumption against RPM at WOB of $20000 \mathrm{lb}$

It is obvious that, fuel consumption increases as RPM increases. The suitable RPM, $160 \mathrm{rpm}$, is obtained at maximum ROP and minimum fuel consumption (Figs. 7 and 8 ). The relationship between flow rate of fluid and RPM is given in Figure 9.

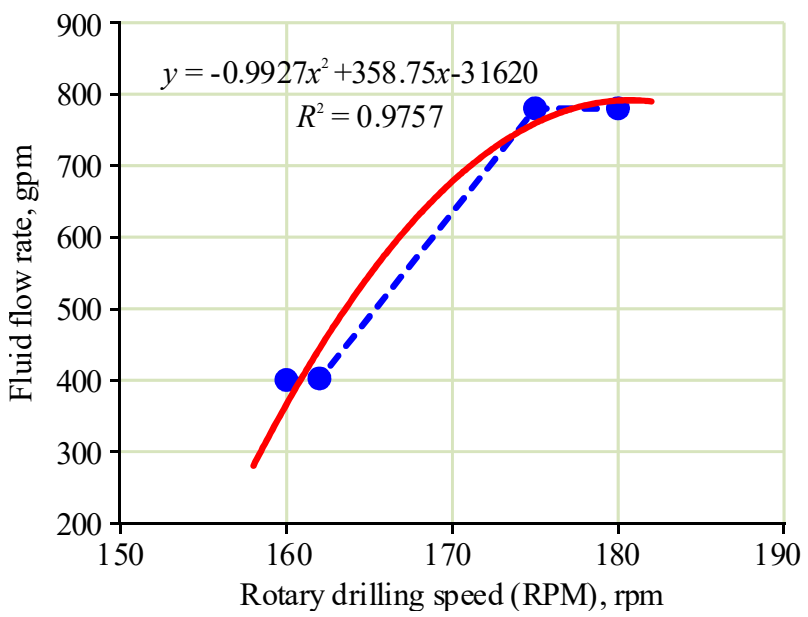

Figure 9. Fluid flow rate versus RPM at WOB of $20000 \mathrm{lb}$

It is shown that, the fluid flow rate increases as drilling RPM increases. 
From these three figures (Figs. 7 - 9), it can be shown that the suitable value of drilling speed is $160 \mathrm{rpm}$ which gives best ROP of $11.2 \mathrm{ft} / \mathrm{hr}$, minimum fuel consumption of $30 \mathrm{gal} / \mathrm{hr}$ and minimum fluid flow rate of $400 \mathrm{gpm}$.

\section{CONCLUSIONS}

It is utmost important to optimize the drilling opera-ting parameters (i.e. WOB, RPM and fluid flow rate) for the best drilling conditions (i.e. maximum ROP and minimum fuel consumption). In this paper, drilling information from El-Sharara Oil Field in Libya is used to determine the suitable drilling conditions with respect to different geological formations. Generally, the ROP increases when WOB increases for both two formations type. In the upper formations, the maximum value of ROP of $21.40 \mathrm{ft} / \mathrm{hr}$ is obtained at low WOB of $19000 \mathrm{lb}$, and high RPM of $175 \mathrm{rpm}$. Whilst, the ROP of $55.4 \mathrm{ft} / \mathrm{hr}$ is reached at high thrust or WOB of $45000 \mathrm{lb}$, and low RPM of $100 \mathrm{rpm}$. Alternatively, ROP is directly proportional to WOB and inversely with RPM. But, ROP decreases when both WOB and RPM increase.

The most suitable value of drilling speed is found to be $100 \mathrm{rpm}$ to produce best ROP (Figs. 4 and 5). Also, the results indicate that, the ROP in the upper formations is 2.5 times that in the lower formations, (i.e. ROP of $21.4 \mathrm{ft} / \mathrm{hr}$ ) compared to $8.8 \mathrm{ft} / \mathrm{hr}$, at the same drilling conditions (i.e. WOB, RPM and fluid flow rate). Thereby, lower formations are harder than upper formations.

When RPM increases the fuel consumption (i.e. high energy consumed) increases for both two different geological formations. Finally, it is recommended to apply heavy WOB with lower RPM of $100 \mathrm{rpm}$ in hard formations (i.e. lower formations) and small WOB with high RPM of $160 \mathrm{rpm}$ in soft formations (i.e. upper formations) to get maximum ROP, minimum fluid flow rate and minimum fuel consumption.

\section{RECOMMENDATIONS}

The following two recommendations are highly advisable:

1. It is not recommended to apply both high WOB and RPM together, it would accelerate drill-bit wear, e.g., heavy loads of weight on bit would create huge friction with rock, and increase the fuel consumption, e.g., due to high speed.

2. For oil well, e.g., NC-186/K.04H, to obtain the best drilling conditions, e.g., maximum ROP, minimum fluid flow rate and minimum fuel consumption, heavy loads on drill-bit, e.g. weight on bit of $45000 \mathrm{lb}$, should be applied at low drilling speed of $100 \mathrm{rpm}$ particularly in hard formations, e.g., lower formations, and small loads of thrust of $19000 \mathrm{lb}$, are used at high drilling speed $160 \mathrm{rpm}$ in the soft formations, e.g. upper formations.

\section{ACKNOWLEDGEMENTS}

The authors declare that the paper has not been originated under any project and no funding has been raised for this research.

\section{REFERENCES}

Abdellah, W. (2007). Drilling parameters in relation to penetration rates, as a tool to predict the type of rock. $\mathrm{PhD}$ Thesis. Assiut, Egypt: University of Assiut.

Abouzeid, A.A., \& Cooper, A.G. (2003). Experimental verification of drilling simulator. In 9th International Conference on Mining, Petroleum and Metallurgical Engineering. Ismailia, Egypt: Suez Canal University.

Ali, M., Abdellah, W., \& Abd El-Aal, A. (2016). Drillability prediction using regression analysis for some Egyptian rocks. International Journal of Research in Engineering and Technology, 05(10), 138-149. https://doi.org/10.15623/ijret.2016.0510023

Bilgin, N., \& Kahraman, S. (2003). Drillability prediction in rotary blast hole drilling. In International Mining Congress and Exhibition of Turkey. Antalya, Turkey.

Clark-Lowes, D.D. (2008). The oil reserves of Libyadiscovered, produced and yet to find: from analysis of the impact of recent new ideas from the reserve base. In $A A P G$ International Conference and Exhibition. Cape Town, South Africa.

Dahl, F., Grøv, E., \& Breivik, T. (2007). Development of a new direct test method for estimating cutter life, based on the Sievers' J miniature drill test. Tunnelling and Underground Space Technology, 22(1), 106-116. https://doi.org/10.1016/j.tust.2006.03.001

EL-Biblawi, M., Sayed, M., Mohamed, M., \& EL-Rawy, W. (2007a). Some drilling parameters as a tool to predict different categories of rocks. Journal of Engineering Sciences, 35(4), 995-1008.

El-Biblawi, M., $\quad$ Sayed, M., $\quad$ Mohamed, M., El-Rawy, W. (2007b). Effect of weight on bit and rotary speed on drilling rate and specific energy using different rocks. In International Conference on Mining, Petroleum and Metallurgical Engineering. Assiut, Egypt: University of Assiut.

El-Biblawi, M., Sayed, M., Boghdady, G., \& Hamdallah, H. (2012). Effect of operating parameters and formation pro-perties on penetration rate in some sandstone rocks by using diamond core bit. Journal of Engineering Sciences, 40(2), 581-594.

Fello, N. (2001). Depositional environments, diagenesis and reservoir modelling of concession NC115, Murzuq Basin, SW Libya. PhD Thesis. Durham, United Kingdom: University of Durham.

Kahraman, S. (1999). Rotary and percussive drilling prediction using regression analysis. International Journal of Rock Mechanics and Mining Sciences, 36(7), 981-989. https://doi.org/10.1016/s0148-9062(99)00050-9

Mellor, M. (1972). Normalization of specific energy values. International Journal of Rock Mechanics and Mining Sciences \& Geomechanics Abstracts, 9(5), 661-663.

Osgouei, R. (2007). Rate of penetration estimation model for directional and horizontal wells. MSc Thesis. Ankara, Turkey: Middle East Technical University.

Pathinkar, A.G., \& Misra, G.B. (1980). Drillability of rocks in percussive drilling from "energy per unit volume" as determined with a microbit. International Journal of Rock Mechanics and Mining Sciences \& Geomechanics Abstracts, 32(9), 1407-1410. https://doi.org/10.1016/0148-9062(81)90698-7

Sayed, M. (1992). Development and optimization of drilling system. PhD Thesis. Assiut, Egypt: University of Assiut.

Sayed, M. (1994). A mathematical model of single bit tooth to relate some drilling parameters. Journal of Engineering Science, 22(2), 219-226.

Sayed, M. (2001). Relation between operating parameters and bit performance in diamond core drilling. In International Conference on Mining, Petroleum and Metallurgical Engineering. Assiut, Egypt: University of Assiut. 
Sayed, M. (2009). Fundamentals of rock drilling. Course for $2^{\text {nd }}$ year mining students. Assiut, Egypt: University of Assiut.

Sayed, M. (2014). Drilling methods and their applications. Course for $3^{\text {rd }}$ year mining students. Assiut, Egypt: University of Assiut.

Sayed, M., \& Boghdady, G. (2010). Optimization of diamond core bit performance utilizing high rotary speed in drilling limestone rocks. Journal of Engineering Sciences, 38(6), 1531-1543. https://doi.org/10.1016/0148-9062(72)90016-2

Seifabad, M.C., \& Ehteshami, P. (2013). Estimating the drilling rate in Ahvaz oil field. Journal of Petroleum Exploration and Production Technology, 3(3), 169-173.

https://doi.org/10.1007/s13202-013-0060-3
Selim, AA, \& Bruce, WE. (1970). Prediction of penetration rate for percussive drilling. US Bureau of Mines RI 7396.

Teale, R. (1965). The concept of specific energy in rock drilling. International Journal of Rock Mechanics and Mining Sciences \& Geomechanics Abstracts, 2(1), 57-73. https://doi.org/10.1016/0148-9062(65)90022-7

Wijk, G. (1991). Rotary drilling prediction. International Journal of Rock Mechanics and Mining Sciences \& Geomechanics Abstracts, 28(1), 35-42.

https://doi.org/10.1016/0148-9062(91)93231-t

\section{ВИЗНАЧЕННЯ ОПТИМАЛЬНИХ ПАРАМЕТРІВ БУРІННЯ У РІЗНИХ ГЕОЛОГІЧНИХ ФОРМАЦІЯХ НАФТОВОГО РОДОВИЩА ЕЛЬ-ШАРАРА (ПІВДЕННО-ЗАХІДНА ЛІВІЯ)}

\section{М.А. Саєд, Г.Є. Богдаді, В.Р. Адбеллах}

Мета. Визначення оптимальних експлуатаційних умов для технологічних параметрів буріння - осьового навантаження на долото (ОНД), швидкості обертального буріння (ШОБ), характеристик бурового розчину на основі емпіричних даних, отриманих на нафтовому родовищі Ель-Шарара.

Методика. У роботі вивчені та систематизовані дані експлуатації нафтової свердловини NC-186/K04h, що містять інформацію про геологічні формації родовища, обсадних колонах, бурових коронках, витрат палива і бурової рідини та інших параметрах буріння.

Результати. Дослідження показало, що, чим нижче розташовані нафтоносні геологічні формації ЕльШарара, тим міцніше породи верхніх формацій. Рекомендовано застосовувати велике навантаження (ОНД близько 104 кг), при низькій ШОБ (100 об/хв) у нижніх формаціях; і мале навантаження (ОНД - 86 кг) при високій ШОБ (160 об/хв) - у верхніх формаціях. Встановлено кореляційний взаємозв'язок комплексу технологічних параметрів буріння з умовами геологічних формацій родовища.

Наукова новизна. Для умов нафтового родовища Ель-Шарара дана наукова оцінка ефективності буріння на основі встановлення взаємозв'язку параметрів формацій і бурових установок.

Практична значимість. Врахування взаємозв'язку геологічних формацій і параметрів механічного буріння дозволить суттєво підвищити швидкість проходки свердловин, при цьому загальні витрати на буріння будуть скорочені за рахунок зменшення часу буріння, споживання палива та збільшення терміну служби бурових коронок.

Ключові слова: оптимізація бурових робіт, експлуатаиійні параметри, властивості порід, буріння нафтових свердловин, нафтове родовище Ель-Шарара

\section{ОПРЕДЕЛЕНИЕ ОПТИМАЛЬНЫХ ПАРАМЕТРОВ БУРЕНИЯ В РАЗЛИЧНЫХ ГЕОЛОГИЧЕСКИХ ФОРМАЦИЯХ НЕФТЯНОГО МЕСТОРОЖДЕНИЯ ЭЛЬ-ШАРАРА (ЮГО-ЗАПАДНАЯ ЛИВИЯ)}

\section{М.А. Саед, Г.Е. Богдади, В.Р. Адбеллах}

Цель. Определение оптимальных эксплуатационных условий для технологических параметров бурения осевой нагрузки на долото (ОНД), скорости вращательного бурения (СВБ), характеристик бурового раствора на основе эмпирических данных, полученных на нефтяном месторождении Эль-Шарара.

Методика. В работе изучены и систематизированы данные о эксплуатации нефтяной скважины NC-186/K04h, которые содержат информацию о геологических формациях месторождения, обсадных колоннах, буровых коронках, расходе топлива и буровой жидкости, а также других параметрах бурения.

Результаты. Исследование показало, что, чем ниже расположены нефтеносные геологические формации Эль-Шарара, тем тверже породы верхних формаций. Рекомендуется применять большую нагрузку (ОНД - около 104 кг), при низкой СВБ (100 вр/мин) в нижних формациях; и малую нагрузку (ОНД - 86 кг) при высокой СВБ (160 вр/мин) - в верхних формациях. Установлена корреляционная взаимосвязь комплекса технологических параметров бурения с условиями геологических формаций месторождения.

Научная новизна. Для условий нефтяного месторождения Эль-Шарара дана научная оценка эффективности бурения на основе установления взаимосвязи параметров формаций и буровых установок.

Практическая значимость. Учет взаимосвязи геологических формаций и параметров механического бурения позволит существенно увеличить скорость проходки скважин, при этом общие затраты на бурение будут сокращены за счет уменьшения времени бурения, потребления топлива и увеличения срока службы буровых коронок.

Ключевые слова: оптимизация буровых работ, эксплуатационные параметры, свойства пород, бурение нефтяных скважин, нефтяное месторождение Эль-Шарара 


\section{ARTICLE INFO}

Received: 16 March 2018

Accepted: 9 July 2018

Available online: 20 July 2018

\section{ABOUT AUTHORS}

Mohamed Ahmed Sayed, Doctor of Philosophy, Professor of the Mining and Metallurgical Engineering Department, University of Assiut, 71516, Assiut, Egypt. E-mail: ma_sayed@aun.edu.eg

Gamal Yehia Boghdady, Doctor of Philosophy, Professor of the Mining and Metallurgical Engineering Department, University of Assiut, 71516, Assiut, Egypt. E-mail: shoeib64@gmail.com

Wael Rashad Abdellah, Doctor of Philosophy, Assistant Professor of the Mining and Metallurgical Engineering Department, University of Assiut, 71516, Assiut, Egypt. E-mail: wre544@gmail.com 